\title{
Volatile Compound Analysis using GC-MS, Phytochemical Screening and Antioxidant Activities of the Husk of "Julang-Jaling" (Archidendron bubalinum (Jack) I.C Nielsen) from Lampung, Indonesia
}

\author{
Candra Irawan ${ }^{1}$, Foliatini ${ }^{1 *}$, Hanafi ${ }^{2}$, Lilis Sulistiawaty ${ }^{1}$ and Maman Sukiman ${ }^{3}$
}

\section{Candra Irawan ${ }^{1}$, Foliatini ${ }^{1 *}$, Hanafi ${ }^{2}$, Lilis Sulistiawaty ${ }^{1}$ and Maman Sukiman ${ }^{3}$}

\section{'Department of Analytical Chemistry Polytechnic of AKA Bogor, Bogor 16158, INDONESIA. \\ 2Department of Food Industrial Quality Assurance Polytechnic of AKA Bogor, Bogor 16158, INDONESIA. ${ }^{3}$ Department of Industrial Waste Treatment Polytechnic of AKA Bogor, Bogor 16158, INDONESIA. \\ Correspondence \\ Dr. Foliatini}

Department of Analytical Chemistry Polytechnic of AKA Bogor, Bogor 16158, INDONESIA.

Phone no :+62-856-7653-523

Fax:+62-251-8650352

E-mail: foliatini@gmail.com

\section{History}

- Submission Date: 25-08-2017;

- Review completed: 11-09-2017;

- Accepted Date: 20-11-2017

DOI : 10.5530/pj.2018.1.17

\section{Article Available online}

http://www.phcogj.com/v10/i1

\section{Copyright}

(C) 2018 Phcog.Net. This is an openaccess article distributed under the terms of the Creative Commons Attribution 4.0 International license.

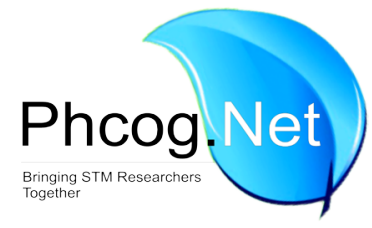

\begin{abstract}
Background: "Julang-jaling" (Archidendron bubalinum (Jack) I.C Nielsen) fruits are commonly used as traditional food and in the treatment of blood sugar and heart disease. However, the research about the phytochemicals of the parts of this plants and their bioactivity was rare. Objective: The recent study was aimed to analyze volatile compounds in the extract of "julang-jaling" husks and evaluate their antioxidant and antimicrobial activities. Material and methods: The extraction was conducted using $n$-hexane, ethyl acetate, and methanol as extracting agent. The phytochemical assay was performed for all extracts, and followed by volatile compound analysis using GC-MS. The antioxidant assay was performed using DPPH method, and the antimicrobial activity was conducted using agar disc diffusion method. Results: The phytochemical assay showed that all extracts of "julang-jaling" husks contain various phytoconstituents having potential bioactivity. All extracts exhibit antioxidant activity with different level of activity depend on the type of extract. The $I C_{50}$ value were $273.57 \mathrm{ppm}$, $324.913 \mathrm{ppm}, 735 \mathrm{ppm}$, for ethyl acetate, methanol and $n$-hexane, respectively. All extracts were able to inhibit the growth of Bacillus cereus, with the highest antimicrobial activity was gained for ethyl acetate extract. Both ethyl acetate and methanolic extract have antimicrobial activity toward E. coli, but no extracts yield positive results for Aspergillus flavus and Aspergillus niger. Conclusion: GC-MS analysis revealed the presence of hexadecanoic acids and their ester form in all extract, which might largely contribute in the antioxidant and antimicrobial activity.

Key words: Archidendron bubalinum (Jack) I.C Nielsen, GC-MS, Phytochemicals, Antioxidant, Antimicrobial Activity.
\end{abstract}

\section{INTRODUCTION}

Archidendron bubalinum (Jack) I.C Nielsen is an evergreen plant indigeneous to Thailand, Peninsular Malaysia and Sumatra in Indonesia, especially in Lampung province. This plant is belongs to Fabaceae or Leguminosae family, and also placed in Mimosaceae. According to Lim (2012), this species has many synonyms e.g Albizia acradena Miq., Cylindrokelupha bubalina (Jack) Kosterm, Feuilleea bubalina (Jack) Kuntze, Inga bubalina Jack, Ortholobium bubalinum (Jack) Kostern, Pithecellobium bigeminum (L.) Mart. var. bubalinum (Jack) Benth., Pithecellobium ellipticum sensu auct., Pithecellobium lobatum sensu Ridley. The fruit of this plant has different local names such as julang-jaling (Lampung), jering utan (Riau), jering kabau (West Sumatra), kabau (Jambi, Palembang, Riau), kabeu (Bengkulu), kerdas or jering tupai (Malaysia), and nieng-no (Thailand). $1,2,3,4,5,6$

The strong pungent smelling fruits have an odor like jering (Archidendron jiringa) and petai (Parkia speciosa).

The fruits have the flavor of jering and are similarly used to flavor food. Young seeds can be eaten raw in ulam or lalapan (traditional vegetable salad) or in chutney. People also used the fruits for treating blood sugar and heart disease.

To our knowledge, the phytochemical composition, antioxidant and antimicrobial activity of the "julang-jaling" husks have not yet been found. Since the husks were potential as herbal medicine, the phytoconstituents of this husks and the relation between the chemicals and their bioactivity should be studied comprehensively. Mass spectrometry, coupled with chromatographic separations such as gas chromatography (GC/MS) is normally used for direct analysis of components existing in traditional medicines and medicinal plants. In recent years GC-MS studies have been increasingly applied for the analysis of medicinal plants as this technique has proved to be a valuable method for the analysis of

Cite this article: Irawan C, Foliatini, Hanafi, Sulistiawaty L, Sukiman M. Volatile Compound Analysis Using GC-MS, Phytochemical Screening and Antioxidant Activities of the Husk of "Julang-Jaling" (Archidendron bubalinum (Jack) I.C Nielsen) From Lampung, Indonesia. Pharmacog J. 2018;10(1):92-8. 
non polar components and volatile essential oil, fatty acids, lipids, alkaloids, terpenoids and steroids, and only few grams of plant material is required. ${ }^{21,22,23}$

In this recent study, we performed extraction process using several solvents and volatile compound analysis of "julang-jaling" (Archidendron bubalinum (Jack) I.C Nielsen) husks using GC-MS technique. The extracts were also evaluated their antioxidant activity using DPPH method and antimicrobial activity using agar disc diffusion method.

\section{MATERIALS AND METHODS}

\section{Plant Materials}

"Julang-jaling" (Archidendron bubalinum (Jack) I.C Nielsen) fruits were harvested from Lampung, Sumatra, Indonesia. The plant was identified by Herbarium Bogoriense, Biological Research Centre, LIPI, Indonesia. The husks were collected from the fresh fruits, and then were washed with running tap water to remove the dirt, prior to the drying process. The husks were cut into small pieces, dried in room temperature, and then were powdered.

All chemicals used were of analytical grade. 1,1-Diphenyl-2-picrylhydrazyl (DPPH), Dragendorff's reagent, Meyer's reagent, methanol, ethyl acetate, $n$-hexane, concentrated sulfuric acid, concentrated $\mathrm{HCl}$, ferric chloride hexahydrate $\left(\mathrm{FeCl}_{3} \cdot 6 \mathrm{H}_{2} \mathrm{O}\right)$, DMSO, acetic acid anhydride, acetic acid glacial, chloroform were purchased from Merck.

\section{Instrumentation}

Solvent removal (after maceration process) was done by rotary evaporator. Separation process was conducted by Thin Layer Chromatography, and further structure elucidation was performed by GC-MS.

\section{Sample Extraction}

Sample preparation was conducted by maceration using several organic solvents. A $100 \mathrm{~g}$ of powdered jolang-jaling husks were immersed in $5 \mathrm{~L}$ of $\mathrm{n}$-hexane for 3 days, and then filtered. Filtrate was evaporated until dry sample was obtained, and this step resulted in raw extract of $\mathrm{n}$-hexane. The residue from first immersion was entirely immersed back in $5 \mathrm{~L}$ ethyl acetate for 3 days to obtain raw extract of ethyl acetate. The solution was then filtered and evaporated, and the residue from this step was immersed in methanol for 3 days, resulted in raw methanolic extract. The maceration process was repeated several times to obtain clear extract solution containing all of expected chemical species.

\section{Phytochemical assay}

Phytochemical assay of raw extract of $n$-hexane, ethyl acetate, and methanol was performed using standard protocols, which have been reported in previous studies. ${ }^{12,13,14}$ The assay included several test for alkaloid, tannin, saponin, flavonoid, phenolic, and terpenoid.

\section{Antioxidant Activity}

Antioxidant activity of extracts was resolved by monitoring radical scavenging activity using DPPH method described in the past with slight modifications. ${ }^{7}$ Briefly, $1 \mathrm{~mL}$ of $0.5 \mathrm{mM} \mathrm{DPPH} \mathrm{(1,1-diphenyl-2-pi-}$ cryl-hydrazil) solution in methanol was pipetted and transferred to vial. The samples were prepared separately to obtain $1 \mathrm{mg} / \mathrm{L}(\mathrm{ppm}), 3 \mathrm{ppm}$, and $5 \mathrm{ppm}$ solution in methanol, and transferred to the vials which contain $0.5 \mathrm{mM} \mathrm{DPPH}$. Each vial was diluted by adding methanol until the total volume of $5 \mathrm{~mL}$. The absorbance of DPPH solution was measured by UV-Vis spectrophotometer at $1=515 \mathrm{~nm}$, every 5 minutes for total of 30 minutes. Antioxidant activity was calculated as a function of absorbance decrease of DPPH solution as a consequence of sample addition.

\section{Structural elucidation of each fraction by GC-MS}

Samples of $n$-hexane, ethyl acetate, and methanol extracts were further analyzed by Gas Chromatography - Mass Spectrometry (GC-MS) to determine the species contained in the samples. The chemical components were identified by matching their mass spectra with those recorded in the mass spectral library. GC-MS analysis was performed by using Agilent 7890A GC system, Agilent 5975C series VL MSD, capilarry column type, flow rate of $1 \mathrm{~mL} / \mathrm{min}$, carrrier gas was helium, constant flow model, injector temperature was $250^{\circ} \mathrm{C}$, injection volume was $2 \mathrm{uL}$, split injection technique, oven temperature was programmed from $40^{\circ} \mathrm{C}$ for $2 \mathrm{~min}$, with temperature increment rate of $10^{\circ} \mathrm{C} / \mathrm{min}$, and final temperature of $280^{\circ} \mathrm{C}$ for $2 \mathrm{~min}$. Total running time was $30 \mathrm{~min}$.

\section{RESULTS AND DISCUSSION}

"Julang-jaling" husks and their extracts have appearance as shown in (Figure 1). After maceration in n-hexane, ethyl acetate and methanol, the as-obtained extracts were then examined through several procedures. The first step is preliminary phytochemical assay to qualitatively analyze the phytoconstituents in the extracts. The second step is antioxidant and antimicrobial assay, to prove the prediction of antioxidant and antimicrobial activity from phytochemical test. The third step is performing GC-MS technique to analyze and predicted the structure of bioactive volatile compounds.

\section{Extraction using n-hexane, ethyl acetate and methanol}

Extraction of the "julang-jaling" seeds was conducted using several solvents, i.e. $n$-hexane, ethyl acetate and methanol, as they represent nonpolar, semipolar and polar solvent, respectively. Previous studies reported that the biologically active phytoconstituents may have polarity from low to high, depend on their chemical structure. ${ }^{25,26,27}$

Extraction of the seeds by maceration in those solvents for several days yielded colored solution: yellow bright for ethyl acetate extract, dark brown for methanolic extract and brownish yellow for $n$-hexane extract, as shown by Figure 2D. After evaporation, the color of the extract solution were reduced. The yields of the extraction were listed in the Table 1 . The highest yields was achieved for methanolic extract, and the lowest yield was obtained for $n$-hexane extract.

\section{Preliminary Phytochemical Assay}

The $n$-hexane, ethyl acetate and methanolic extracts of "julang-jaling" (Archidendron bubalinum (Jack) I.C Nielsen) husks were subjected to several phytochemical test for the detection of different phytocompounds using standard procedures. The results were shown in Table 2.

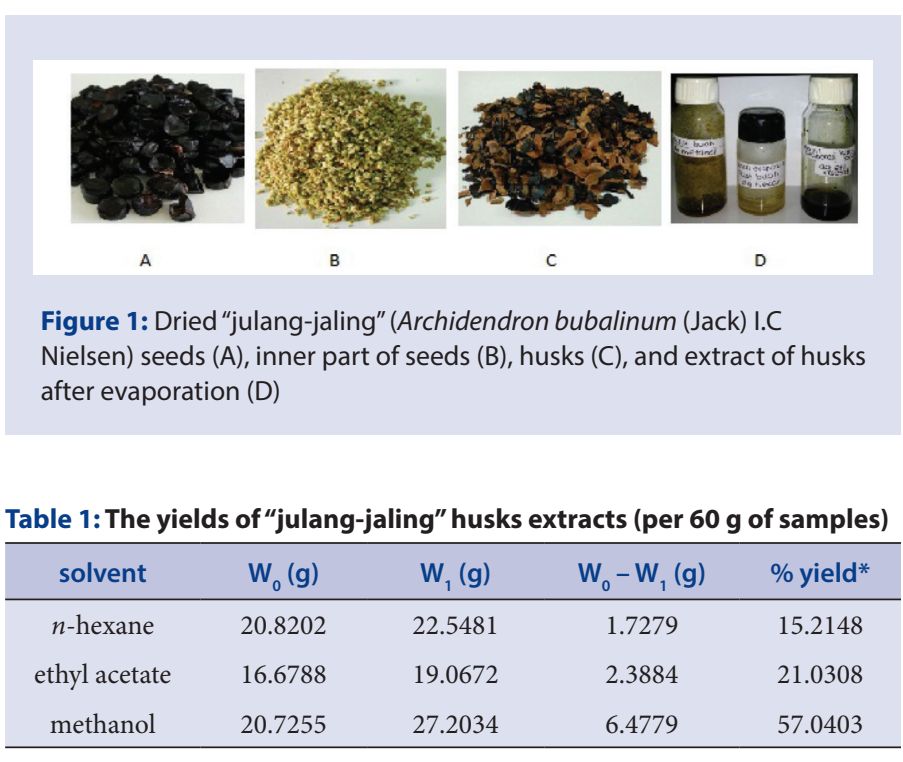

$* \%$ yield is calculated using the followed equation : $\left(\left(\mathrm{W}_{0}-\mathrm{W}_{1}\right) / 60\right) \times 100 \%$ 
Table 2 : Phytochemical assay of extract of "julang-jaling" (Archidendron bubalinum (Jack) I.C Nielsen) husks

\begin{tabular}{cccc}
\hline \multirow{2}{*}{ Phytochemicals } & \multicolumn{3}{c}{ Extracting agent } \\
\cline { 2 - 4 } & hexane & ethyl acetate & methanol \\
\hline Alkaloids : & & - & - \\
- Meyer & +++ & ++++ & + \\
-Dragendorf & +++ & - & \\
-Wagner & +++ & - & ++ \\
Flavonoids & +++ & +++ & +++ \\
Tannins & +++ & +++ & +++ \\
Phenols & - & ++ & - \\
Saponins & + & + & + \\
Terpenoids & +++ & &
\end{tabular}

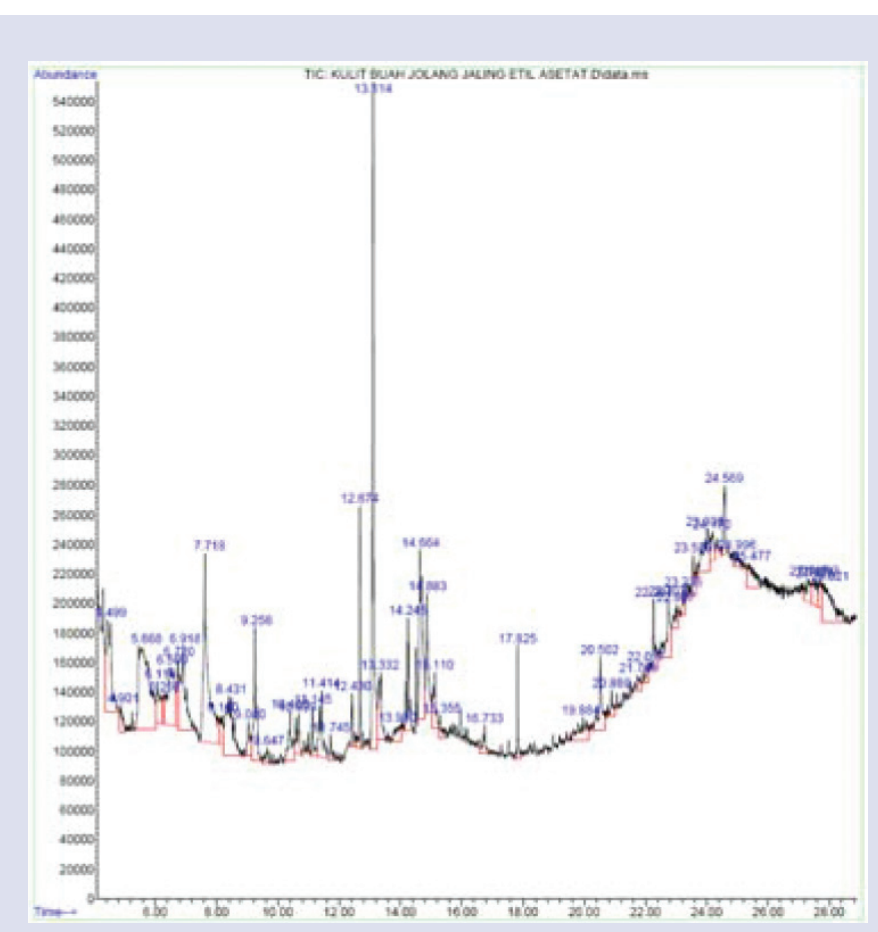

Figure 2 : GC-MS analysis performed of ethyl acetate extract

Table 3 : Antioxidant activity of "julang-jaling" (Archidendron bubalinum (Jack) I.C Nielsen) husks extracts

\begin{tabular}{cc}
\hline Extracting agent & $\mathrm{IC}_{50}(\mathrm{ppm})$ \\
\hline ethyl acetate & $273.57 \mathrm{ppm}$ \\
hexane & $735 . \mathrm{ppm}$ \\
methanol & $324.913 \mathrm{ppm}$ \\
\hline
\end{tabular}

Phytochemical screening of various plants has been reported by many workers. ${ }^{15,16,17}$ These studies have revealed the presence of numerous chemicals, including alkaloids, flavonoids, tannin, phenols, saponins and terpenoids.

Table 2 showed that all extracts contain alkaloid, tannins, and terpenoids, although the concentration was varied for each extract. Both ethyl acetate and methanolic extracts contain phenols. Flavonoids were present in both $n$-hexane and methanolic extract, whereas saponins were present

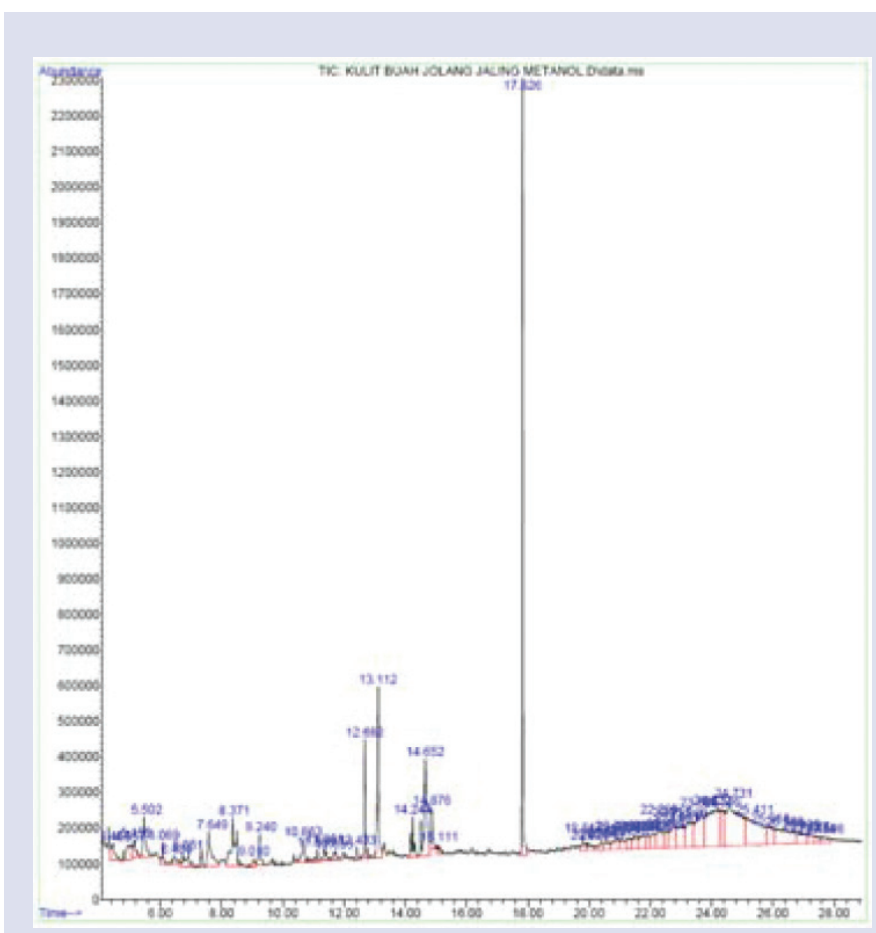

Figure 3 : GC-MS analysis performed of metanol extract

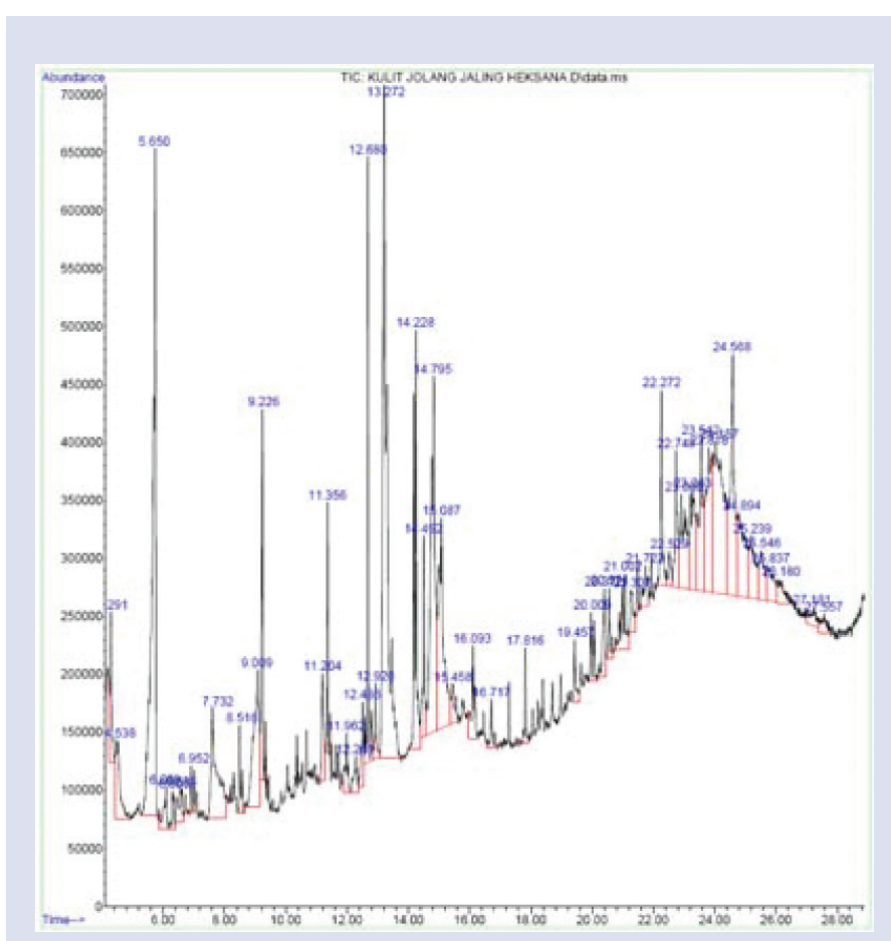

Figure 4 : GC-MS analysis performed of hexane extract

in both $n$-hexane and ethyl acetate extract. The $n$-hexane extract exhibited negative yields for phenols test.

A number of studies have focused on the biological activities of tannins, phenols, flavonoid and terpenoid compounds, which are antioxidants and free radical scavengers. ${ }^{1}$ Thus, based on the phytochemical assay, all extracts may be predicted to possess significant antioxidative and anti- 
microbial properties. In order to evaluate the antioxidant and antimicrobial activity of all extracts, we performed antioxidant assay using DPPH method, and antimicrobial assay using agar disc diffusion method.

\section{Antioxidant Assay}

The $n$-hexane, Antioxidant assay of all extracts was conducted using DPPH method. The DPPH free radical method is an easy, rapid and sensitive technique to evaluate the antioxidant activity of certain compounds, including extract of plants. ${ }^{24}$ In this technique, the antioxidant compounds were able to reduce the DPPH radicals, resulting color change of the solution from deep violet to yellow. The decrease in absorbance at wavelength of $517 \mathrm{~nm}$ was recorded and converted to \% inhibition. Antioxidant activity was reported as $\%$ inhibition, and this values were then plotted as a function of extract concentration to obtain $\mathrm{IC}_{50}$ value. The lower the $\mathrm{IC}_{50}$ value, the higher the antioxidant capacity.

The result showed that all extracts give rise to the $\%$ inhibition as the concentration was increased, thus these extracts possessed a certain degree of antioxidant activity. Table 3 showed that the methanolic extract have $\mathrm{IC}_{50}$ value of $324.913 \mathrm{ppm}$ and the ethyl acetate have $\mathrm{IC}_{50}$ value of $273.57 \mathrm{ppm}$ or have moderate antioxidant activity. However, the $n$-hexane showed high $\mathrm{IC}_{50} 735 \mathrm{ppm}$, thus the extracts have low antioxidant activity. This result was in agreement with the qualitative prediction from phytochemical assay. Various phytoconstituents which largely contained in the ethyl acetate and methanolic extract were responsible for the antioxidant activity of these extracts.

In order to evaluate the chemical compounds which may have large contribution to the antioxidant activity of the ethyl acetate and methanolic extract, and explained the absence of the antioxidant activity for $n$-hexane extracts, the GC-MS analysis was conducted for all of the extracts

\section{Antimicrobial Assay}

Antimicrobial assay was conducted for all of extracts toward 2 strains of bacteria (Bacillus cereus and E. coli) as representatives of Gram positive and Gram negative bacteria, respectively, and 2 strains of fungi (Aspergillus flavus and Aspergillus niger). The assay was performed by measuring inhibition zone around the disk. The results of the assay were shown in Table 4 . According to the categorization by David Stout, ${ }^{19}$ the inhibition zone of $<5 \mathrm{~mm}$ was categorized as low activity, $5-10 \mathrm{~mm}$ as moderate activity, and $>10 \mathrm{~mm}$ as strong activity.

According to the Table 4, it is clear that all extracts have ability to inhibit the growth of Gram positive bacteria Bacillus cereus, but were not able to inhibit the growth of fungi. The highest inhibition ability against microorganism was shown by ethyl acetate extract with inhibition zone of $19 \mathrm{~mm}$, or categorized as strong (stronger than antiobiotic standard of penicillin). The $n$-hexane and methanolic extract exhibited low to moderate activity against the bacteria. Both ethyl acetate and methanolic extract have antimicrobial activity toward Gram negative bacteria E. coli. The antimicrobial activity of the extracts were simply explained by result of the phytochemical assay, which revealed many constituents with antimicrobial potency.

The phenolic groups in the extract may inhibit the growth of bacteria through the formation of protein-phenolic groups between hydroxyl groups and cell membrane of protein, resulting the disruption of the cell membrane and causing the death of the bacteria. ${ }^{32}$ According to previous study, the Gram negative bacteria constituted of complex cell walls besides peptidoglycans, i.e. outer cell wall composed of liposaccharide, lipoprotein, and peptide attached- periplasm. The proin type-lipoprotein is hydrophilic and cannot interact with hydrophobic antibacterial. ${ }^{31}$

The difficulties of the three types of extracts in penetrating the sterol membranes at the cell wall of fungi caused the growth of the Aspergillus flavus and Aspergillus niger fungi cannot be inhibited, as shown by the
Table 4 : Antimicrobial assay of "julang-jaling" (Archidendron bubalinum (Jack) I.C Nielsen) husk extracts

\begin{tabular}{ccccc}
\hline \multirow{2}{*}{ Extract $^{* 1}$} & \multicolumn{5}{c}{ Inhibition zone (mm) } \\
\cline { 2 - 5 } & $\begin{array}{c}\text { Bacillus } \\
\text { cereus }\end{array}$ & E. coli & $\begin{array}{c}\text { Aspergillus } \\
\text { flavus }\end{array}$ & $\begin{array}{c}\text { Aspergillus } \\
\text { niger }\end{array}$ \\
\hline$n$-hexane & 2 & - & - & - \\
ethyl acetate & 19 & 5 & - & - \\
methanol & 5 & 3 & - & - \\
standard ${ }^{* 2}$ & 15 & 20 & 20 & 3 \\
\hline
\end{tabular}

${ }^{* 1}$ the extract concentration were the same for all type of extracts

*2 the standard used in the experiment was amoxillin for bacteria and ketokonazole for fungi.

Table 5 : GC-MS analysis of ethyl acetate extract

\begin{tabular}{ccccc}
\hline No & Constituents & $\begin{array}{c}\text { Retention } \\
\text { time }(\min )\end{array}$ & \% Area & \% Similarity \\
\hline 1 & $\begin{array}{c}\text { Hexadecanoic acid, } \\
\text { methyl ester }\end{array}$ & 12.670 & 2.81 & 99 \\
2 & $\begin{array}{c}\text { Hexadecanoic acid } \\
3\end{array}$ & 13.111 & 9.22 & 92 \\
4 & $\begin{array}{c}\text { 9-octadecenoic acid, } \\
\text { methyl ester } \\
\text { (Z)-11- }\end{array}$ & 14.241 & 2.00 & 95 \\
\hline & Octadecenoic acid & 14.664 & 5.62 & 94 \\
\hline
\end{tabular}

Table 6 : GC-MS analysis of methanolic extract

\begin{tabular}{ccccc}
\hline No & Constituents & $\begin{array}{c}\text { Retention } \\
\text { time }(\min )\end{array}$ & \% Area & \% Similarity \\
\hline 1 & $\begin{array}{c}\text { Hexadecanoic acid, } \\
\text { methyl ester }\end{array}$ & 12.679 & 1.80 & 99 \\
2 & Hexadecanoic acid & 13.111 & 4.24 & 98 \\
4 & $\begin{array}{c}\text { 6-octadecenoic acid, } \\
\text { methyl ester }\end{array}$ & 14.241 & 1.29 & 93 \\
5 & $\begin{array}{c}\text { (Z)-11-Octadecenoic } \\
\text { acid }\end{array}$ & 14.655 & 4.61 & 99 \\
6 & Octadecanoic acid & 14.879 & 1.00 & 91 \\
\hline
\end{tabular}

clear zone diameter of zero. The growth of fungi was more difficult to be inhibited by antimicrobial agent since the cell wall of fungi was constructed from rigid material such as chitin, glucan, and mannan, and the extract of plants (or parts of plants) have no capability in blocking the synthesis of such rigid materials. ${ }^{31}$

The further analysis performing by GC-MS instrumentation could provide a more detail elucidation of the phytochemicals, thus capable of explaining the structure of the compounds which act as major contributor for the bioactivity of the extracts.

\section{GC-MS Analysis}

GC chromatogram of the extracts were shown in Figure 2, 3, 4 and the predicted constituents in the extracts were listed in 2-7. A total of 27 compounds were found in $n$-hexane extract, 4 compounds in ethyl acetate extract, and 6 compounds in methanolic extract. It can be understood that there was larger amount of compounds found in $n$-hexane, compared to that found in ethyl acetate and methanolic extract, since the GC-MS technique only performed well for analyzing volatile com- 
Table 7 : GC-MS analysis of $\boldsymbol{n}$-hexane extract

\begin{tabular}{|c|c|c|c|c|}
\hline No & Constituents & Retention time (min) & $\%$ Area & $\%$ Similarity \\
\hline 1 & 1-(1-Butyldithio) Butane & 5.649 & 9.01 & 91 \\
\hline 2 & (2E)-3-Phenyl-2-Propenoic Acid & 7.735 & 2.91 & 90 \\
\hline 3 & 2,4-Di-tert-butylphenol & 9.013 & 3.24 & 91 \\
\hline 4 & Lenthionin $1,2,3,5,6$-Pentathiepane & 9.224 & 2.20 & 94 \\
\hline 5 & Tetradecanoic acid & 11.200 & 0.98 & 97 \\
\hline 6 & 9-icosene (trans)-2-nonadecene & 11.068 & 0.68 & 90 \\
\hline 7 & Hexadecanoic acid, methyl ester & 12.679 & 2.89 & 99 \\
\hline 8 & 1-Pentadecane carboxylic acid & 13.267 & 12.25 & 91 \\
\hline 9 & cis-13-Octadecenoic acid, methyl ester & 14.223 & 3.68 & 95 \\
\hline 10 & methyl stearate & 14.490 & 1.32 & 90 \\
\hline 11 & 5-(4-nitrophenyl)-1,3,4-oxadiazol-2(5h)-one & 19.461 & 0.46 & 90 \\
\hline 12 & 1,3,4-Oxadiazol-2(3H)-one, 5-(4-nitrophenyl) & 20.013 & 0.68 & 95 \\
\hline 13 & 3-Dimethylamino-2-(4-chlorphenyl)-thioacrylamide & 21.308 & 0.67 & 95 \\
\hline 14 & 5-(4-nitrophenyl)-1,3,4-oxadiazol-2(5h)-one & 22.237 & 1.42 & 90 \\
\hline 15 & 5-(4-nitrophenyl) & 22.253 & 0.38 & 93 \\
\hline 16 & 5-(4-nitrophenyl)-1,3,4-oxadiazol-2(5h)-one & 22.999 & 2.32 & 97 \\
\hline 17 & (2E)-2-(4-Chlorophenyl)-3-(dimethylamino)-2-propen-ethioamide & 23.284 & 2.14 & 96 \\
\hline 18 & 3-Dimethylamino-2-(4-chlorphenyl)-thioacrylamide & 23.542 & 2.88 & 95 \\
\hline 19 & 5-(4-nitrophenyl)-1,3,4-oxadiazol-2(5h)-one & 23.817 & 3.90 & 95 \\
\hline 20 & 2-p-nitrophenyl-oxadiazol-1,3,4-one-5 & 24.157 & 6.45 & 97 \\
\hline 21 & 2-p-nitrophenyl-oxadiazol-1,3,4-one-5 & 24.892 & 2.76 & 98 \\
\hline 22 & 2-p-nitrophenyl-oxadiazol-1,3,4-one-5 & 25.242 & 1.68 & 98 \\
\hline 23 & 5-(4-nitrophenyl)-1,3,4-oxadiazol-2(5h)-one & 25.545 & 1.18 & 95 \\
\hline 24 & 5-(4-nitrophenyl)-1,3,4-oxadiazol-2(5h)-one & 25.839 & 0.96 & 96 \\
\hline 25 & (2E)-2-(4-Chlorophenyl)-3-(dimethylamino)-2-propen ethioamide & 26.179 & 0.74 & 95 \\
\hline 26 & (2E)-2-(4-Chlorophenyl)-3-(dimethylamino)-2-propen ethioamide & 27.181 & 0.50 & 96 \\
\hline 27 & 1,3,4-Oxadiazol-2(3H)-one, 5-(4-nitrophenyl) & 27.557 & 0.46 & 95 \\
\hline
\end{tabular}

pounds, which largely contained in the $n$-hexane extract compared to that in the ethyl acetate and methanolic extract.

Table 5 revealed that the ethyl acetate extract contains fatty acid ester (hexadecanoic acid, methyl ester and 9-octadecenoic acid, methyl ester) and carboxylic acid (hexadecanoic acid and (Z)-11-octadecenoic acid). Palmitic acid ester (hexadecanoic acid, methyl ester) have various bioactivities including antifungal, antioxidant, hypocholesterolemic, nematicide, pesticide, antiandrogenic flavour, haemolytic, 5-alpha reductase inhibitor, potent antimicrobial activity. ${ }^{29}$ Hexadecanoic acid is also has the same properties as explained above, based on Duke's Phytochemical and Ethnobotanical Database and Jim Duke Agricultural Research Service/ USDA. ${ }^{30}$ Phytochemical compound of 9-octadecenoic acid, methyl esters have been reported as Antibacterial and antifungal. ${ }^{28}$ Based on the potent activity of the phytocompound, the antioxidant and antimicrobial activity shown by ethyl acetate extracts were mostly due to the content of hexadecanoic acids and their ester form.

Table 6 revealed that the composition of the methanolic extract similar to that of the ethyl acetate extract. This simply explained why the bioactivity of the two extracts were similar, both antioxidant and antimicrobial activity.

Table 7 revealed that the main constituents in the $n$-hexane extract includes alkanes, alkenes, ester, ketones, carboxylates, amide, phenolic and aromatic compounds. Except phenolic groups and of methyl ester of hexadecanoic acid, those compounds do not possess any conjugates double bonds or functional groups which have reducing capacity, thus they could hardly show any antioxidant activity. This phenomenon can be seen from the percentage of inhibition of the $n$-hexane extract which was much lower than that of ethyl acetate and methanolic extracts. Though phenolic groups is widely known as an antioxidative agent, their presence in this extract might be very low, as supported by the absence of this groups in the phytochemical assay. The GC-MS analysis performed in the experiment did not use any standard solution, thus the quantity of each fraction cannot be exactly calculated. It implied that the relatively high percentage of area of phenolic compounds may not represent the high concentration of these species in the sample extract.

\section{CONCLUSION}

The phytochemical assay showed that both ethyl acetate and methanolic extracts of "julang-jaling" husks contain various phytoconstituents having potential bioactivity. GC-MS analysis revealed the presence of hexadecanoic acids and their ester form in ethyl acetate and methanolic extract, which might largely contribute in the antioxidant and antimicrobial activity. Ethyl acetate, methanol and $n$-hexane extracts showed antioxidant activity with $\mathrm{IC}_{50}$ value of $273.57 \mathrm{ppm}, 324.913 \mathrm{ppm}$, and 735 ppm, respectively. All extracts also have capability to inhibit the 
growth of Bacillus aureus, with the highest inhibition properties was achieved for ethyl acetate extract. The results showed that all extracts exhibit antioxidant and antimicrobial properties, thus "julang-jaling" could be recommended as plant of pharmaceutical importance.

\section{ACKNOWLEDGMENT}

This work was partially supported by Department of Chemical Analysis, Department of Food Industrial Quality Assurance, and Department of Industrial Waste Treatment Polytechnic of AKA Bogor, Bogor 16158, Indonesia.

\section{CONFLICT OF INTEREST}

The authors declare that they have no conflict of interest.

\section{ABBREVIATION USED}

GC-MS: Gas Chromatography Mass Spectrometry; DPPH: Diphenylpicrylhydrazyl.

\section{REFERENCES}

1. Sova M. Antioxidant and antimicrobial activities of cinnamic acid derivatives. Mini Rev Med Chem . 2012;12(8):749-67.

2. Zhu B, Shang B, LiY, Zhen Y. Inhibition of histone deacetylases by trans-cinnamic acid and its antitumor effect against colon cancer xenografts in athymic mice Mol Med Rep. 2016;13(5):4159-66

3. Lim K. Edible Medicinal and Non-Medicinal Plants. Edible Medicinal and Non-Medicinal Plants. 2012;2:1-95.

4. Nielsen IC. Mimosaceae (Leguminosae-Mimosoideae). Flora Malesiana Foundation. 1992;11(1):1-226.

5. Ghazalli MN, Masrom H, OmarY, Aishah-Farhana S. A preliminary flora survey in Gunung Kajang, PulauTioman, Pahang Darul Makmur, Malaysia. Malays. Appl. Biol. 2014;43(2):17-23.

6. Heyne K. De Nuttige Planten van Nederlandsch Indie. Departement LNH Ned. Indie. 1927.

7. Brand-Williams W, Cuvelier ME, Berset C. Use of a free radical method to evaluate antioxidant activity Food Science and Technology. 28(1):25-30.

8. Hwa Jang K, Ho Lee B, Wook Choi B, Shin J. Chromenes from the Brown Alga Sargassum siliquastrum. Journal of Natural Products. 2005:68(5):716-23.

9. Cho SH, Cho JY, Kang SE, Hong YK, Ahn DH. Antioxidant activity of mojabanchromanol, a novel chromene, isolated from brown alga Sargassum siliquastrum. J Environ Biol. 2008;29(4):479-84.

10. Lasemi J, Azimi R, Azizi Amri M. Efficient synthesis of 9,10-dihydropyrano[2,3H] chromene-2,8-dione derivatives in ionic liquid and the study of their antioxidant activity Natural Product Research. 2017. 31

11. Seo Y, Eui Park K., Jeong Nam T.. Isolation of a New Chromene from the Brown Alga Sargassum thunbergii. Korean Chem. Soc. 2007;28(10).

12. Kayani SA, Masood A, Achakzai AKK, Anbreen S. Distribution of secondary metabolites in plants of Quetta-Balochistan. Pakistan Journal of Botany. 2007;39(4):1173-9.

13. Khan M, Qureshi RA, Ullah F. Phytochemical analysis of selected medicinal plants of Margalla hills and surroundings. Journal of Medicinal Plant Research. 2011;5(25):6017-23

14. Ayoola GA, Coker H, Adesegun SA. Phytochemical screening and antioxidant activities of some selected medicinal plants used for malaria therapy in Southwestern Nigeria. Tropical Journal of Pharmaceutical Research. 2008;7(3):1019-24.

15. SelvarajS, Chittibabu CV, Janarthanam B. Studies on phytochemical screening antioxidant activity andextraction of active compound (swertiamarin) from leafextract of enicostemma littorale Asian Journal Of Pharmaceutical And Clinical Research. 2014; 7.

16. Ahmad S, Ahmad S, Bibi A, Saqib Ishaq M, Siddique Afridi M, Kanwal F, Zakir M, Fatima F. Phytochemical Analysis, Antioxidant Activity, Fatty Acids Composition, and Functional Group Analysis of Heliotropium bacciferum. The Scientific World Journal 2014.

17. Iqbal E, Abu Salim K, Linda Lim BL. Phytochemical screening, total phenolics and antioxidant activities of bark and leaf extracts of Goniothalamus velutinus (Airy Shaw) from Brunei Darussalam. Journal of King Saud University Science. 2015;27(3):224-32.

18. Parimalakrishnan AK, Rajeswari, Ravikumar Extraction and characterization of phytoconstituents of Cleome chelidonii by GC/MS. International Journal of Chemical and Pharmaceutical Sciences. 2015;6(1)

19. Hema R, Kumaravel S, Alagusundaram K. GC/MS determination of bioactive components of Murraya koenigii.. J Am Sci. 2011;7(1):80-3.

20. Syeda FA, Habib-ur-Rehman M, Choudahry I, Atta-ur-Rahman. Gas chromatography-mass spectrometry (GC-MS) analysis of petroleum ether extract (oil) and bio-assays of crude extract of Iris germanica,. International Journal of Genetics and Molecular Biology. 2011;3(7):95-100.

21. Jie MSF, Choi CYCJ. Int. Fed. Clin. Chem. . 1991;3,122.

22. Betz JM, GayML, Mossoba MM, Adams S, Portz BS. J AOAC Int. 80, 303

23. M. Sermakkani, V. Thangapandian (2012). gc-ms analysis of cassia italica leaf methanol extract. Asian Journal of Pharmaceutical and Clinical Research. 1997;5(2):90-4.

24. Huang DJ, Ou BX, Prior RL. J. Agric. Food Chem. 2005;53,1841-56.

25. Kumari M., Jain Res S. Tannins: An Antinutrient with Positive Effect to Manage Diabetes. J. Recent Sci. 2012.;1(12):70-3.

26. Alexei YB, Joseph IS, Olga YF. Pharmacognostical and Phytochemical Evaluation Leaves Extract of Garcinia daedalanthera Pierre. Pharmacol. 2009;61:9-38.

27. Zheng H, Sun X, Guo N, Li R, Afr J. Microb. Res. 2014;8:2315-21.

28. Chandrasekaran M., Senthilkumar A., Venkatesalu V. Antibacterial and antifungal efficacy of fatty acid methyl esters from the leaves of Sesuvium portulacastrum L. Med. Pharmcol. Sci. 2011;15(7):775-80.

29. Parimalakrishnan S, Akalanka Dey, Rajeswari J, Ravikumar K. International Journal of Chemical and Pharmaceutical Sciences. 2015;6(1):63-9.

30. Mustaffa F, Indukar J, Ismail S, Shah M, Mansor SM. An Antimicrobial Compound Isolated from Cinnamomum Iners Leaves with Activity against MethicillinResistant Staphylococcus Aureus.. Molecules. 2011;16(4):3037-47.

31. Mangunwardoyo W, Deasywaty, Usia T. Antimicrobial and Identification of Active Compound Curcuma xanthoriza Roxb. International Journal Basic and Applied Sciences IJBAS-IJENS. 2012;12(01):69-78.

\section{GRAPHICAL ABSTRACT}

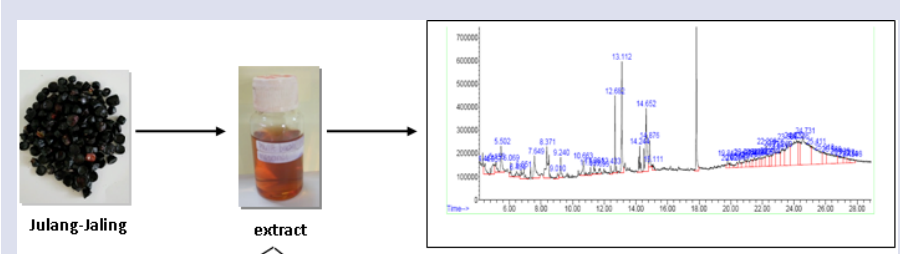

Julang-Jaling

GC-MS Analysis

\section{SUMMARY}

- Methanolic extract of Julang - Jaling husks was proven to contain large amount of phytochemicals especially alkaloids, flavonoids, tannins and phenol.

- Methanolic extract of Julang - Jaling husks possessed significant antioxidant activity.

- Methanolic extract of Julang - Jaling husks also showed antimicrobial activity against Bacillus cereus. 


\section{ABOUT AUTHORS}

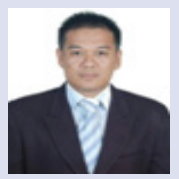

Candra Irawan: Holds a Master Degree in Chemistry from University of Indonesia in 2010 and currently he is a lecturer in Department of Chemical Analysis, Polytechnic of AKA Bogor, Indonesia. His research focuses on phytochemistry and natural product science.

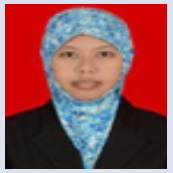

Foliatini: Is a Lecturer in Polytechnic of AKA Bogor. Complete her Doctoral Degree in Chemistry from University of Indonesia in 2015. Her research focuses on metal nanoparticles, biopolymer and antioxidant from extract of various plants.

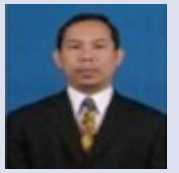

Hanafi: Holds a Master Degree in Chemistry from University of Indonesia in 2006 and currently he is a lecturer in department of quality assurance of food industry, Polytechnic of AKA Bogor, Indonesia. His research focuses on functional food and natural product - based food packaging.

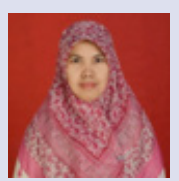

Lilis Sulistiawaty: Holds a Master Degree in Chemistry from Bogor Agriculture University in 2014 and currently she is a lecturer in department Department of Chemical Analysis, Polytechnic of AKA Bogor, Indonesia. Her research focuses on metal nanoparticles, biopolymer and antioxidant from extract of various plants.

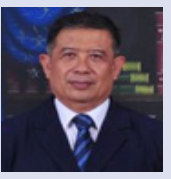

Maman Sukiman: Holds a Master Degree in Gricultural technology from Bogor Agriculture University in 2000 and currently he is a lecturer in Department of Industrial Waste Treatment, Polytechnic of AKA Bogor, Indonesia. His research focuses on natural products and wastewater treatment using agricultural waste.

Cite this article: Irawan C, Foliatini, Hanafi, Sulistiawaty L, Sukiman M. Volatile Compound Analysis Using GC-MS, Phytochemical Screening and Antioxidant Activities of the Husk of "Julang-Jaling" (Archidendron bubalinum (Jack) I.C Nielsen) From Lampung, Indonesia. Pharmacog J. 2018;10(1):92-8. 